\title{
Reproductive Performance of Holstein Friesian Dairy Cows at Alage Dairy Farm, Ethiopia
}

\author{
Berihulay Haile ${ }^{1 *}$ and Mekash Yoseph ${ }^{2}$ \\ ${ }^{1}$ Alage Agricultural Technical Vocational Educational and Training College, Ethiopia \\ ${ }^{2}$ International Livestock Research Institute (ILRI), Ethiopia
}

Submission: May 26, 2018; Published: August 20, 2018

*Corresponding author: Berihulay Haile, Alage Agricultural Technical Vocational Educational and Training College, Ethiopia, Tel: +251913239890;

Email: haile.berihulay@yahoo.com

\begin{abstract}
This study was conducted to optimize the reproductive parameters of Holstein Friesian cows at Alage dairy farm, Ethiopia. Reproduction data were included; the age at first service (AFS), age at first calving (AFC), calving to first service interval (CFSI), first service conception rate (FSCR), number of services per conception (NSC), inter service interval (ISI), pregnancy rate (PR) and calving rate (CR) of cows and were collected from the herds' databases from 14 years. The independent fixed variables were year and season of birth/calving and parity. Data were analyzed using the general linear models of SAS software. The overall least square means ( \pm SE) for AFS, AFC, CFSI, FSCR, NSC, ISI, PR and CR of the herds were $27.07 \pm 0.24$ months, $37.10 \pm 0.26$ months 156 days, $75.50 \pm 2.30 \%, 1.9,32$ days, $81.30 \%$, and $76.92 \%$, respectively. The calving season had a significant $(\mathrm{P}<0.05)$ effect on FSCR, NSC, ISI, and PR which displayed higher values in the long rainy season than in the dry season. Parity had significant effects on CRFS $(\mathrm{P}<0.05)$ and PR $(\mathrm{P}<0.05)$. The results showed that the values of AFC, CFSI and ISI were lower than the standard expected values in dairy herd. These indicate that the dairy herd needs an improved management. Hence, to improve the efficiency of reproductive performances of the cows; proper heat detection, health care, adequate feeding and reproductive problems of heifers should be considered.
\end{abstract}

Keywords: Calving rate; Conception rate; Holstein Friesian; Pregnancy rate; Reproductive performance; Dairy farm; Adequate feeding; Heat detection; Health care; Cows; Ecto- parasites; Mastitis; Tuberculosis; Breeding

Abbreviations: AFS: Age at First Service; AFC: Age at First Calving; NSC: Number of Services per Conception; PR: Pregnancy Rate; CFSI: Calving to First Service Interval; CR: Calving Rate; FSCR: First Service Conception Rate; ISI: Inter Service Interval

\section{Introduction}

Reproductive performance is one of the most important concerns of the modern dairy industry worldwide. Improved fertility increases profit by reducing culling costs and by increasing incomes from milk sales and shorter calving intervals. However, it has been shown that the reproductive performance of dairy cows has declined during recent decades in many countries in the world [1]. The causes for decreasing fertility in dairy cattle are of multifactorial origin, and the relevance of different management factors varies depending on the geographical area of study and the herd [2]. In Ethiopia the major causes include poor management and nutrition (both quality and quantity), manifestation of disease and genetic factors [3].

Genetic factors affect reproductive performance, but in most studies, heritability estimates for calving interval or days open has been $5 \%$ or less [4]. This means that genetic factors are likely to explain only a small proportion of variation in fertility within a population of cows and suggests the strong influence of non-genetic factors such as management decisions. Some studies have suggested that a higher risk of fertility failure in high-producing dairy cows occurred only under sub-optimal conditions such as inadequate nutrition or environment [5]. For many years, Ethiopia has made efforts to improve the reproduction performance of dairy cows, mainly through crossbreeding indigenous cows with exotic HF since 1950's. These efforts have been continued during recent decades. Improved management and nutrition and genetic selection for high milk producing are among these activities (Ministry of Agriculture, National Artificial Insemination Center; www.moa.org). Thus, it is important to identify determinants of reproductive outcomes. There is no large-scale study to evaluate the current reproductive performance of dairy cows in intensive dairy farm and its determinants in Ethiopia. The objectives of the present study were to evaluate the current reproductive parameters of HF dairy cows in Alage dairy farm. 


\section{Materials and Methods}

\section{Ethics Statement}

Animal Care and Use Committee approval was not obtained for this retrospective study because all the data used were included recorded data from the farm of HF dairy cow in Alage, Ethiopian.

\section{The Study Area}

The study was conducted at Alage dairy farm which is located at $217 \mathrm{~km}$ Southwest of Addis Ababa on the way to Hawassa city. Geographically the study site is located at about 380 30' East and $7030^{\prime}$ 'North at an altitude of 1600 meters above sea level. The area is characterized by mild subtropical weather with the minimum and maximum temperature ranging from $11^{\circ} \mathrm{C}$ to $29^{\circ} \mathrm{C}$. The area experiences bimodal rainfall distribution with annual average of $700-900 \mathrm{~mm}$. The rainfall pattern is bimodal over the months; average moisture is $56 \%$. The three defined seasons based on rainfall distribution are: short rainy season (March- April); long rainy season (June to September) and long dry season (October - February).

\section{Dairy Cattle Management}

The dairy cattle are managed with dairy cattle management system and the feed stuff includes hay, green feed and concentrates at Alage Ethiopia. Dairy cows receive a daily maintenance ration of about $2 \mathrm{~kg}$ concentrate with an additional production ration of up to $1 / 2 \mathrm{~kg}$ per $\mathrm{kg}$ of milk yield. Cows over seven months pregnancies are provided with up to $4 \mathrm{~kg}$ concentrates per day. Newborn calves suckle their dams until five days from birth to get colostrum. Thereafter they are bucket fed and the amount varies according to age. From 5 to 35 days of age calves receive up to 5 liters of milk per day, from 35 to 65 days of age to 4 liters and from 85 to 100 days of age up to 2 liters. Besides, they are given about one liter of milk per day until they are weaned at the age of 120 days.

\section{Breeding Operation}

The Alage dairy farm was established in 1983 with 300 females and 4 males of HF breed which came from a few of private dairy farms around Stella, Holetta, and private dairy farms around Addis Ababa. The parent stock of HF was imported from Stella, Holetta, and Addis Ababa. The aim of the farm was milk production. The breeding weight for heifers in the farm is $300 \mathrm{~kg}$. Rest period allowance for cows is 45 to 60 days. Cows are culled if they require greater than 5 insemination services per conception and have serious mastitis infections. Male calves are not selected for future breeding purpose and are culled at 3 months age. Regular preventive treatments were administered against prevalent endo- and ecto-parasites. Mastitis, Tuberculosis and Abortion, were common on clinical case book records.

\section{Data Collection Procedure}

A retrospective study was carried out to evaluate reproductive performances of HF dairy cows. The data were collected from 1999 to 2013 and included calving dates, dates of first and subsequent artificial insemination. Information were collected to estimate; the age at first service, age at first calving, first service conception rate, number of services per conception, calving to first service interval, inter service interval, calving rate and pregnancy rate. Close observation and secondary recorded data were used to assess management practice of the farm. The parameters were estimated as follows:

a. Age at first service the number of days from birth to the date of first service.

b. Age at first calving was obtained by the number of days from birth to the date of Calving

c. Calving to first service interval was calculated as the number of days from calving to the date of first insemination service.

d. First service conception rate was obtained by determining the percentage of cows/heifers that become pregnant at the first insemination after calving. Cows that become pregnant by the first service designated were reported as $100 \%$ FSCR, whereas, cows required more than one service became pregnant 0\% FSCR.

e. Inter service interval was determined as the number of days between two successive services through lactation of cow with repeated services.

f. Number of services per conception was determined as the number of services required for successful conception from breeding records.

g. Pregnancy rate was represented as the ratio of conception number to the number of services, which was expressed as percentage. Cows that became pregnant at the first service designated were recorded as $100 \%$ PR, whereas, cows given 2, 3, 4, and 5 services were reported for $50,33.3$, 25 and $20 \%$ PR, respectively.

h. Calving rate was determined as number of calf born per cow per year

\section{Data Analysis}

The data collected were entered Microsoft excel software for preliminary assessment of data distribution. The fixed effects in the study were year of birth/calving, season of birth/calving and parity. Three seasons were established based on weather and climatic conditions of the area: June to September as long rain season, March to May as short rainy season and October to February as dry season. Since there were no sufficient recorded data, year of calving/birth were categorized into seven years: year-1 (1999-2000), year-2 (2001-2002), year-3 (2003-2004), year-4 (2005-2006), year-5 (2007-2008), year-6 (2009-2010) and year-7 (2011 -2013). Six parities were considered since only few cows that had completed more than 6 lactations. After preliminary assessment the data were subjected to analysis of 
variance using the General Linear Models of SAS [6]. The model was: -

$$
\mathrm{Y}_{\mathrm{ijklm}}=\mu+\mathrm{YR}_{\mathrm{j}}+\mathrm{S}_{\mathrm{k}}+\mathrm{Pl}+\mathrm{e}_{\mathrm{ij \textrm {jlm }}}
$$

Where:

$\mathrm{Y}_{\mathrm{ijklm}}=$ the $\mathrm{m}^{\text {th }}$ record $(\mathrm{AFC}, \mathrm{AFS}$ CFSI, CR, FSCR, ISI, NSC and $\mathrm{PR}$ ) of $\mathrm{i}^{\text {th }}$ cow in lth parity, $\mathrm{j}^{\text {th }}$ year of calving, $\mathrm{k}^{\text {th }}$ season of calving.

$\mu=$ overall mean

$\mathrm{YR}_{\mathrm{j}}=$ the fixed effect of $\mathrm{j}^{\text {th }}$ year of calving $(\mathrm{j}=1,2,3 \ldots 7 ; 1=1999$ $2000 ; 2=2001-2002 \ldots . . .7=2011-2013$ )

$\mathrm{S}_{\mathrm{k}}=$ the fixed effect of $\mathrm{k}^{\text {th }}$ season of calving $(\mathrm{k}=1,2,3 ; 1=$ dry season (Oct-Feb.); 2=short rainy season (March-May); 3= Long (main) rainy season (June-Sept.)

$\mathrm{P}_{1}=$ the fixed effect of lth parity $(\mathrm{l}=1,2,3,4,5,6$ and above $)$

$\mathrm{e}_{\mathrm{ijk} \mathrm{km}}=$ random residual error term

Results

\section{Age at First Service (AFS) and Age at First Calving (AFC)}

The AFS is the age at which heifers attain body condition and sexual maturity for accepting service for the first time whereas; AFC is the age at which heifers calve for the first time. The average means for AFS and AFC for HF dairy cows in the study area were 27 and 37 months, respectively (Table 1). The analysis of variance showed that both AFS and AFC were significantly $(p<0.001)$ influenced by years of birth, but not by seasons of birth $(p>0.05)$. The present result showed AFS and AFC were shorter for cows in year 2011 - 2013 but longer in year 19992000.

Table 1: Least square means (LSM) for Age at first service and Age at first calving of Holstein Frisian cows at Alage dairy farm.

\begin{tabular}{|c|c|c|c|}
\hline Age at First Service & \multicolumn{2}{|c|}{ Age at First Calving } & $\begin{array}{c}\text { Age at First } \\
\text { Calving }\end{array}$ \\
\hline Variables & \multicolumn{2}{|c|}{ (month) } & (month) \\
\hline & $\mathrm{N}$ & $\mathrm{LSM} \pm$ SE & LSM \pm SE \\
\hline Overall mean & 189 & $27.07 \pm 0.24$ & $37.10 \pm 0.26$ \\
\hline Years of birth & & ${ }^{* * *}$ & $* * *$ \\
\hline $1999-2000$ & 44 & $29.66 \pm 0.50^{\mathrm{a}}$ & $39.81 \pm 0.54^{\mathrm{a}}$ \\
\hline $2001-2002$ & 30 & $27.10 \pm 0.63^{\mathrm{b}}$ & $36.79 \pm 2.76^{\mathrm{b}}$ \\
\hline $2003-2004$ & 15 & $28.62 \pm 0.87^{\mathrm{ab}}$ & $39.80 \pm 3.90^{\mathrm{ab}}$ \\
\hline $2005-2006$ & 22 & $26.59 \pm 0.72^{\mathrm{bc}}$ & $36.60 \pm 3.00^{\mathrm{b}}$ \\
\hline $2007-2008$ & 42 & $27.60 \pm 0.53^{\mathrm{ab}}$ & $37.35 \pm 3.86^{\mathrm{b}}$ \\
\hline $2009-2010$ & 26 & $27.16 \pm 0.66^{\mathrm{b}}$ & $37.30 \pm 2.73^{\mathrm{b}}$ \\
\hline $2011-2013$ & 10 & $22.79 \pm 1.28^{\mathrm{c}}$ & $32.33 \pm 0.92^{\mathrm{c}}$ \\
\hline Seasons of birth & & $\mathrm{ns}$ & $\mathrm{ns}$ \\
\hline Dry season & 89 & $27.76 \pm 0.39$ & $37.58 \pm 0.42$ \\
\hline
\end{tabular}

a-cLSmean with different superscripts in the same column for the same effects are significantly different;

${ }^{* * *}=p<0.001 ;{ }^{* *}=p<0.01 ;{ }^{*}=p<0.05 ;$ ns: Not Significant; $N$ : Number of observation; SE: Standard Error.

\section{Calving to First service Interval (CFSI) and First Service Conception Rate (FSCR)}

The CFSI is the average number of days from calving to the day of first insemination served; but, FSCR is the percentage of females pregnant after first breeding or the ratio of animals confirmed pregnant at the first service to the number of cows bred. The average means for CFSI and FSCR for Holstein Frisian dairy cows in the study area were 156 days and $75.50 \pm 2.30 \%$, respectively (Table 2 ).

Table 2: Least square means for Calving to First service Interval (CFSI) and First Service Conception Rate (FSCR) of Holstein Frisian cows at Alage dairy farm.

\begin{tabular}{|c|c|c|c|c|}
\hline & \multicolumn{2}{|c|}{ CFSI (days) } & \multicolumn{2}{|c|}{ (FSCR \%) } \\
\hline Variables & $\mathbf{N}$ & $\mathrm{LSM} \pm \mathrm{SE}$ & $\mathbf{N}$ & $\mathrm{LSM} \pm \mathrm{SE}$ \\
\hline $\begin{array}{l}\text { Overall } \\
\text { mean }\end{array}$ & 322 & $155.52 \pm 4.43$ & 366 & $75.50 \pm 2.30$ \\
\hline $\begin{array}{l}\text { Year of } \\
\text { Calving }\end{array}$ & & $* * *$ & & $* * *$ \\
\hline $1999-2000$ & 14 & $193.25 \pm 22.98^{\mathrm{a}}$ & 16 & $12.93 \pm 16.01^{b}$ \\
\hline 2001-2002 & 17 & $186.22 \pm 20.26^{a}$ & 15 & $13.29 \pm 11.78^{b}$ \\
\hline $2003-2004$ & 34 & $173.55 \pm 15.44^{\mathrm{a}}$ & 52 & $24.50 \pm 7.80^{\mathrm{b}}$ \\
\hline $2005-2006$ & 22 & $164.17 \pm 11.17^{\mathrm{a}}$ & 27 & $62.19 \pm 4.25^{\mathrm{a}}$ \\
\hline $2007-2008$ & 57 & $172.54 \pm 17.77^{a}$ & 68 & $80.34 \pm 5.79^{a}$ \\
\hline $2009-2010$ & 58 & $105.64 \pm 10.72^{\mathrm{b}}$ & 58 & $68.99 \pm 5.97^{\mathrm{a}}$ \\
\hline $2011-2013$ & 120 & $93.27 \pm 7.91^{\mathrm{b}}$ & 130 & $92.07 \pm 8.92^{\mathrm{a}}$ \\
\hline $\begin{array}{c}\text { Season of } \\
\text { Calving }\end{array}$ & & ns & & ns \\
\hline Dry season & 143 & $164.09 \pm 8.86$ & 149 & $45.60 \pm 5.16$ \\
\hline $\begin{array}{c}\text { Short rainy } \\
\text { season }\end{array}$ & 83 & $160.40 \pm 10.92$ & 92 & $50.22 \pm 6.22$ \\
\hline $\begin{array}{l}\text { Long rainy } \\
\text { season }\end{array}$ & 96 & $142.07 \pm 9.80$ & 125 & $56.02 \pm 5.39$ \\
\hline Parity & & ns & & $* * *$ \\
\hline 1 & 173 & $173.15 \pm 18.48$ & 188 & $23.18 \pm 5.88^{c}$ \\
\hline 2 & 73 & $158.72 \pm 10.20$ & 74 & $36.91 \pm 3.86 b^{c}$ \\
\hline 3 & 41 & $150.02 \pm 13.33$ & 36 & $51.94 \pm 8.14 \mathrm{a}^{\mathrm{b}}$ \\
\hline 4 & 31 & $143.31 \pm 15.59$ & 28 & $71.113 \pm 11.01^{a}$ \\
\hline 5 & 22 & $150.49 \pm 18.32$ & 21 & $75.32 \pm 10.31^{\mathrm{a}}$ \\
\hline 6 and above & 22 & $157.43 \pm 7.42$ & 19 & $45.23 \pm 8.95^{\mathrm{b}}$ \\
\hline
\end{tabular}

${ }^{a-c}$ LSmean with different superscripts in the same column for the same effects are significantly different; ${ }^{* * *}=p<0.001 ;{ }^{* *}=p<0.01 ;{ }^{*}=$ p $<0.05$; ns: Not Significant; N: Number of Observation; SE: Standard Error.

Year of calving had significant $(\mathrm{p}<0.001)$ effect on both CFSI and FSCR. The mean CFSI was significantly $(\mathrm{p}<0.001)$ longest for cows that calved in year 1, 2, 3, 4 and 5 compared to year 6 and 7. The FSCR was significantly $(\mathrm{p}<0.001)$ lower in year 1 , 2 and 3 whereas, an increasing trend was observed from year 4 onwards. Parity had significant $(\mathrm{p}<0.001)$ effect on FSCR but not on CFSI. The mean FSCR was lower in parity 1, 2, and 6 but higher at parity 3,4 and 5 . 


\section{Number of service per conception (NSC) and Inter Ser- vice Interval (ISI)}

The NSC is the number of services (natural or artificial), required for successful conception. The number of inseminations required to produce a live calf is one of the most useful parameters of reproductive efficiency which mainly depends on the breeding system used. Inter service interval is the interval of days between two successive services. The overall mean value for NSC and ISI of HF cows in this study was 1.9 and 32 days, respectively (Table 3).

Table 3: Least square means for Number of service per Conception (NSC) and Inter Service Interval (ISI) for Holstein Frisian cows at Alage Dairy farm.

\begin{tabular}{|c|c|c|c|c|}
\hline & \multicolumn{2}{|c|}{ NSC } & \multicolumn{2}{|c|}{ ISI (days) } \\
\hline Variables & $\mathbf{N}$ & LSM \pm SE & N & LSM \pm SE \\
\hline $\begin{array}{c}\text { Overall } \\
\text { mean }\end{array}$ & 352 & $1.92 \pm 0.48$ & 153 & $31.57 \pm 1.12$ \\
\hline $\begin{array}{c}\text { Year of } \\
\text { Calving }\end{array}$ & & $* * *$ & & $* * *$ \\
\hline $1999-2000$ & 16 & $2.77 \pm 0.17^{\mathrm{a}}$ & 11 & $45.40 \pm 4.65^{\mathrm{a}}$ \\
\hline $2001-2002$ & 13 & $2.45 \pm 0.25^{\mathrm{a}}$ & 9 & $31.89 \pm 5.02^{\mathrm{ab}}$ \\
\hline $2003-2004$ & 42 & $2.57 \pm 0.34^{\mathrm{a}}$ & 25 & $35.01 \pm 3.47^{\mathrm{ab}}$ \\
\hline $2005-2006$ & 27 & $1.58 \pm 0.09^{\mathrm{b}}$ & 9 & $32.50 \pm 4.95^{\mathrm{ab}}$ \\
\hline $2007-2008$ & 66 & $1.41 \pm 0.12^{\mathrm{b}}$ & 25 & $27.66 \pm 3.29^{\mathrm{b}}$ \\
\hline $2009-2010$ & 56 & $1.40 \pm 0.12^{\mathrm{b}}$ & 23 & $26.37 \pm 3.13^{\mathrm{b}}$ \\
\hline $2011-2013$ & 130 & $1.26 \pm 0.19^{\mathrm{b}}$ & 51 & $24.25 \pm 2.39^{\mathrm{b}}$ \\
\hline $\begin{array}{c}\text { Season of } \\
\text { Calving }\end{array}$ & & $\mathrm{ns}$ & & $*$ \\
\hline Dry season & 141 & $1.93 \pm 0.11$ & 73 & $33.36 \pm 2.27^{\mathrm{a}}$ \\
\hline $\begin{array}{c}\text { Short rainy } \\
\text { season }\end{array}$ & 91 & $1.89 \pm 0.13$ & 44 & $35.10 \pm 2.64^{\mathrm{a}}$ \\
\hline $\begin{array}{c}\text { Long rainy } \\
\text { season }\end{array}$ & 120 & $1.94 \pm 0.11$ & 36 & $27.14 \pm 2.82 \mathrm{~b}$ \\
\hline $\begin{array}{c}\text { Parity } \\
1\end{array}$ & 176 & $2.47 \pm 0.12^{\mathrm{a}}$ & 90 & $34.14 \pm 1.79$ \\
\hline 2 & 74 & $2.15 \pm 0.08^{\mathrm{a}}$ & 29 & $35.30 \pm 2.81$ \\
\hline 3 & 35 & $1.90 \pm 0.19^{\mathrm{ab}}$ & 10 & $32.99 \pm 4.81$ \\
\hline 6 and above & 18 & $1.82 \pm 0.17^{\mathrm{b}}$ & 8 & $27.78 \pm 5.14$ \\
\hline
\end{tabular}

a-cLSmean with different superscripts in the same column for the same effects are significantly different; ${ }^{* * *}=p<0.001 ;{ }^{* *}=p<0.01 ;{ }^{*}=p<0.05$; ns: Not Significant; N: Number of Observation; SE: Standard Error.

Year of calving and parity were significantly $(p<0.001)$ influenced NSC, but season of calving had no effect. Number of service per conception was significantly higher in year 1, 2 and 3 but, lower from year 4 onwards. Similarly, NSC was higher in the 1 st and 2 nd parity while lower in the 4 th and 5 th parity. Year and season of calving was significant $(p<0.001)$ effect on ISI but, parity had no effect.

\section{Pregnancy Rate (PR) and Calving Rate (CR)}

Pregnancy rate is the percentage of animals serviced which become pregnant Evelyn [7]. However, CR was defined as the number of calves born per 100 services [8]. The overall mean PR and CR of the dairy herd was 81.30 and $76.92 \%$, respectively Table 4. Season of calving and parity were significant $(\mathrm{p}<$ 0.05) effect on PR, but not year of calving. Pregnancy rate was significantly higher during long rainy season compared to short and dry rainy seasons. The PR at the 5th parity was significantly higher than the 1st parity. On the other hand, CR was significantly $(p<0.001)$ affected by year of calving, but not by season of calving and parity.

Table 4: Least square means for Pregnancy Rate and Calving Rate (CR) of Holstein Frisian cows.

\begin{tabular}{|c|c|c|c|c|}
\hline \multirow[b]{2}{*}{ Variables } & \multicolumn{2}{|c|}{ PR (\%) } & \multicolumn{2}{|c|}{ CR (\%) } \\
\hline & $\mathbf{N}$ & $\mathrm{LS} \pm \mathrm{SE}$ & $\mathbf{N}$ & $\mathrm{LSM} \pm \mathrm{SE}$ \\
\hline $\begin{array}{c}\text { Overall } \\
\text { mean }\end{array}$ & 362 & $81.30 \pm 1.38$ & 292 & $76.92 \pm 0.85$ \\
\hline $\begin{array}{l}\text { Year of } \\
\text { Calving }\end{array}$ & & ns & & $* * *$ \\
\hline $1999-2000$ & 16 & $71.74 \pm 7.18$ & 13 & $65.99 \pm 5.13^{b}$ \\
\hline 2001-2002 & 14 & $81.69 \pm 9.75$ & 15 & $76.38 \pm 5.68^{\mathrm{ab}}$ \\
\hline $2003-2004$ & 52 & $79.07 \pm 4.53$ & 25 & $72.01 \pm 3.37^{\mathrm{ab}}$ \\
\hline $2005-2006$ & 27 & $85.04 \pm 5.45$ & 27 & $71.66 \pm 3.14^{\mathrm{ab}}$ \\
\hline 2007-2008 & 68 & $83.95 \pm 3.54$ & 63 & $75.55 \pm 2.09^{\mathrm{ab}}$ \\
\hline 2009-2010 & 56 & $83.49 \pm 3.63$ & 57 & $85.56 \pm 2.08 \mathrm{a}$ \\
\hline $2011-2013$ & 129 & $84.14 \pm 2.69$ & 92 & $91.25 \pm 1.69 a$ \\
\hline $\begin{array}{l}\text { Season of } \\
\text { Calving }\end{array}$ & & * & & ns \\
\hline Dry season & 147 & $78.10 \pm 3.15 b$ & 135 & $74.64 \pm 1.91$ \\
\hline $\begin{array}{c}\text { Short rainy } \\
\text { season }\end{array}$ & 91 & $78.31 \pm 3.84 b$ & 75 & $77.97 \pm 2.35$ \\
\hline $\begin{array}{l}\text { Long rainy } \\
\text { season }\end{array}$ & 124 & $87.50 \pm 3.27 a$ & 82 & $78.14 \pm 2.12$ \\
\hline Parity & & $*$ & & ns \\
\hline 1 & 186 & $72.05 \pm 2.31^{\mathrm{b}}$ & 123 & $74.51 \pm 1.52$ \\
\hline 2 & 74 & $77.29 \pm 3.67^{\mathrm{ab}}$ & 66 & $74.56 \pm 2.22$ \\
\hline 3 & 35 & $85.11 \pm 4.94^{\mathrm{ab}}$ & 40 & $77.30 \pm 2.75$ \\
\hline 4 & 28 & $84.75 \pm 5.64^{\mathrm{ab}}$ & 27 & $81.09 \pm 3.25$ \\
\hline 5 & 21 & $89.96 \pm 6.26^{\mathrm{a}}$ & 20 & $76.14 \pm 3.74$ \\
\hline 6 and above & 18 & $78.66 \pm 7.20^{\mathrm{ab}}$ & 16 & $77.89 \pm 4.13$ \\
\hline
\end{tabular}

a-cLSmean with different superscripts in the same column for the same effects are significantly different; ${ }^{* *}=p<0.001 ;{ }^{* *}=p<0.01 ;{ }^{*}=p<0.05$; ns: Not Significant; N: Number of Observation; SE: Standard Error.

\section{Discussion}

\section{Age at First Service}

The mean AFS (27 months) revealed in the present study is higher than the reported value of 24.9 and 25.6 months by Belay et al. \& Hunduma $[9,10]$ for crossbred cows at Jimma, and Asella, 
respectively. However, Gebeyehu et al. [11] reported higher mean value of AFS 36.8 months. The significant effect of year of birth on AFS in this study was consistent with the findings of Mureda \& Mekuriaw [12]. The reason for late age at first service in this study could be due to irregularities in management services and feed supply. Year and seasons of birth had no marked effect ( $p>0.05$ ) on AFS; which could be consistent with the finding of Giday [13] on dairy cows.

\section{Age at First Calving}

The mean AFC (37 month) obtained in the present study is higher than 30.7 months reported for HF cows by [14] in Egypt and 29.3 months reported by Ajili et al. [15] in Tunisia; however, lower than 39.2 months reported by Tadesse et al (2010) in central highland Ethiopia. The prolonged AFC of HF cows in the present study compared to literature could be attributed to factors such as poor nutrition and management practices including poor heat detection at the time of mating the heifers. A significant reduction in AFC from 39.8months (1999-2000 year) to 32.33 months (2011-2013 years) which may be indication of progressive improvement in management, replacement of heifers and also adaptation of HF breed to the prevailing tropical environment. An earlier AFC can reduce rearing costs due to decreased feed, labor and building costs. A similar study in previous economic analysis showed that reducing AFC from 25 to 24 or 21 months decreased replacement costs by $4.3 \%$ or $18 \%$ respectively [16]. Conversely increasing AFC to 29 months increased replacement costs by $14 \%$. An increased AFC requires herds to keep more replacement heifers in order to maintain herd size, whilst reducing AFC allows surplus heifers to be sold, maximizing herd profitability.

\section{Calving to First Service Interval}

The mean CFSI (156 days) obtained in the current study was higher than the value 111 and 115 days reported by $[17,18]$ for HF breeds in Turkey and Central Highland Ethiopia, respectively. Similarly, this result is higher than the optimum recommended range of 75 to 90 days for well managed dairy farm [19]; however, lower than 175 and 184 days reported by Samsson \& Mekonnen et al. $[20,21]$ for crossbred dairy cows in central highland and Arsi-Negelle Ethiopia, respectively. Longer CFSI might be due in proper heat detection and in efficient AI skill. In addition, in the present study people involved in heat detection are only present at regular office hours when they should be present at very specific hours because the pattern of heat onset is variable. However, CFSI was linearly decreasing from year group 1 to year group 7. This might be an indication of progressive change in management system as year advances. The effect of year of calving on CFSI in the present study agreed with the result of Tadesse et al. \& Gebregziabher et al. [18,19].

Tadesse et al. [18] stated that poor estrus detection by herdsman and poor estrus expression by dairy cows contributes to long CFSI. Although, under intensive modern dairy production system where animals are housed in the dairy barn (concrete floor) it is very difficult for the animal to adequately manifest behavioral oestrus including mounting activity.

\section{First Service Conception Rate}

The estimated mean FSCR of $75.5 \%$, in this study was higher than the values of $45.9,46.6 \%$ and $46.7 \%$ which were reported by Mureda \& Mekuriaw et al. [12,20,22], for cross breeds, respectively. However, lower than $78 \%$ reported by Habtamu et al. [23] for Jersy cows at Wolaita Sodo dairy farm, Ethiopia. The FSCR was very low in year 1,2 , and 3 as compared to the other years; this might be indicating that there is improvement of herd management. Season of calving and parity number had significant $(p<0.05)$ effect on FSCR this might be due to availability of green fodders. Similar findings were reported by Hammoud et al. [14] who associated improved fertility with optimal environmental temperature and available green fodder. Non-significant effect of season and parity number on FSCR was reported by Habtamu et al. [23]. Year of calving had no significant $(\mathrm{p}<0.001)$ effect on FSCR while Habtamu et al. \& Hammoud et al. [14,23] reported a significant $(\mathrm{p}<0.001)$ effect on FSCR.

\section{Number of Service Per-conception}

The number of services per conception (1.9) reported in the present study is higher than the range of 1.3 to 1.6 recommended as optimum for well managed dairy herd by however, lower than 2.2 obtained for HF cows in Tunisia [24]. Conversely, Tadesse et al. [18] reported 1.8 SPC which was comparable result to this study for HF dairy cattle in Central highland Ethiopia. The significantly $(\mathrm{P}<0.05)$ effect of year observed in NSC in the present study could be related to the variation in feeding and management practices; this is in agreement with result of Mekonnen et al. [25]. Besides, proper and accurate heat detection is a key to efficient reproduction and four to five checks each day to determine the onset of true standing heat gives a better idea when to inseminate.

Number of services per conception tended to decrease significantly $(\mathrm{p}<0.05)$ with parity number until parity 5 but, slightly increase trend was observed at parity 5 . The relative higher NSC for cows in latter parities ( 6 and above) is similar with NSC of 2.19 for parity 6 reported by [26]. Successful service depends on many factors such as quality of semen, skill of the inseminator, proper time of insemination and cows related factors. Season of conception had no significant effect on the NSC in this study. Similarly, absence of seasonal effects on NSC was reported by Tadesse et al. [18,27]. However, Gifawosen et al. [28] found a significantly less NSC in the wet season.

\section{Inter Service Interval}

The overall mean (32 days) ISI recorded in the present study was higher than the recommended range of 18 to 24 days. Fikru [29] reported that a comparable value of 29.2 days. In contrast, Mekonnen et al.\& Gebregziabher et al. [25,30] reported higher 
value of 39.8 and 49.1 days for crossbred dairy cows in ArsiNegelle and Bako, Ethiopia, respectively. The higher values of ISI may be due to improper heat detection, missed or silent heat, the presence of ovarian cyst or embryonic mortality and nutritional factors this is consistent with study. The ISI was significantly influenced by year of calving. It was long in the previous year group compared the recent years; this might be due to lack of consistent management such as heat detection and shortage of experienced inseminators. Furthermore, the result suggested that during recent year cows returning to heat after insemination were inseminated short after and efficiency of heat detection has been improved as well.

Season of calving had significant $(\mathrm{p}<0.05)$ effect on ISI but parity had no influence. This might be due to the moderate climatic conditions and abundant green fodder available during this period. This is consistent with the report of Mekonnen et al. [21] which suggested that ISI might be affected by silent heat, the presence of ovarian cyst or embryonic mortality and higher ambient temperature.

\section{Pregnancy Rate}

The overall mean $(81.30 \%)$ PR obtained in the present study is within the optimum recommended range of 80 - 85\% Evelyn (2001). Pregnancy rate of the current study was comparable with 79.3\% reported by Yoseph et al. [31] for crossbred dairy cows in central highlands of Ethiopia. However, higher than 54.15\% and 72.8\% reported by Emebet \& Haileyesus [32,33] for crossbred dairy cows in in Dire Dawa and Gonder, Ethiopia. Season of calving and parity were significant $(p<0.05)$ effect on $P R$, but not year of calving. The PR was significantly higher during long rainy season compared to short and dry rainy seasons; this might be due to the moderate climatic conditions and abundant green fodder available. Similarly, PR at 5th parity was significantly higher than the 1st parity; this could be associated to delay on resumption of ovarian activities in the 1st parity. Azage [34] showed that during periods of adequate nutrition, fertility rates such as, pregnancy rates in Boran cows improved ranging from 80 to $94 \%$. With respect to management practice, accurate diagnose and monitoring pregnancy status as early as possible after service and detection of non-pregnant animals before the first expected return to oestrus 18 to 24 days after service would be ideal [35].

\section{Calving Rate}

In this study, the $76.92 \%$ mean of CR was within the optimum recommended range of $75-80 \%$ in well managed dairy herd and was higher than (ranged from of 56 to $62 \%$ ) the report of Galato's [36] and 63.4\% reported by Emebet for crossbred dairy cows. Year of calving were significantly $(p<0.001)$ affected by CR, but not affected by season of calving and parity $[37,38]$. The CR during the last 6-7 years were significantly $(p<0.001)$ higher than the previous years. The results suggested that the CR of the herd improved from year to year. This trend could be due to the improved management and better feeding over those years.

\section{Conclusion}

This study revealed that as year advance progressive management improvements in most of the detected reproductive variables were observed. However, CFSI and ISI were still below the optimum level recommended for profitable dairy herd this might be lack of proper heat detection, missed or silent heat, presence of ovarian cyst or embryonic mortality and nutritional factors. Since the result for number of service per conception is within the normal range that expected for modern dairy farm, poor expression of estrus, failure to detect estrus by AI technician or both may be the major causes for low reproduction performance of HF cows in the farm. This calls to give high attention to proper heat detection, well skilled AI technician and proper feeding. Furthermore, better reproductive health management is also required.

\section{Acknowledgement}

This study was financially supported by the Ministry of agriculture. The authors gratefully acknowledge to Alage dairy farm manager for the great cooperation offered during the period of study.

\section{References}

1. Lopez-Gatius F (2003) Is fertility declining in dairy cattle? A retrospective study in northeastern Spain. Theriogenology 60(1): 8999.

2. Yaniz J, Lopez-Gatius F, Bech-sabat G, Garcia-Ispierto I, Serrano B, et al. (2008) Relationships between milk production, ovarian function and fertility in high-producing dairy herds in north-eastern Spain. Reproduction in Domestic Animals 4: 38-43.

3. Dobson H, Smith R, Royal M, Knight Ch, Sheldon I (2007) The highproducing dairy cow and its reproductive performance. Reproduction in Domestic Animals 2: 17-23.

4. Haile-Mariam M, Bowman PJ, Goddard ME (2003) Genetic and environmental relationship among calving interval, survival, persistency of milk yield and somatic cell count in dairy cattle. Livestock Production Science 80: 189-200.

5. Calus MP, Windig JJ, Veerkamp RF (2005) Associations among descriptors of herd management and phenotypic and genetic levels of health and fertility. Journal of Dairy Science 88: 2178-2189.

6. SAS (Statistical Analysis System) (2008) SAS Institute Inc. Cary, NC, USA.

7. Evelyn CG (2001) Reproductive performance of crossbred cattle developed for milk production in the semi-arid tropics and the effect of feed supplementation. A PhD thesis submitted to University of Zimbabwe, p. 165.

8. Peters A, Ball PJ (1995) Reproduction in Cattle. ( $2^{\text {nd }}$ edn), Blackwell Science Ltd. p. 1-75.

9. Belay Duguma, Yisehak Kechero, Janssens GPJ (2012) Productive and Reproductive Performance of Zebu X Holstein-Friesian Crossbred Dairy Cows in Jimma Town, Oromia, Ethiopia. Global Veterinarian 8 (1): 67-72.

10. Hunduma Dinka (2012) Reproductive performance of crossbred dairy cows under smallholder condition in Ethiopia. International Journal of Livestock Production 3(3): 25-28.

11. Gebeyehu GA, Asmare, Asseged B (2005) Reproductive performances of Fogera cattle and their Holstien Friesian crosses in Andassa ranch, 
Northwestern Ethiopia. Livestock research for Rural Development 17: 131.

12. Mureda E, Mekuriaw Zeleke Z (2007) Reproductive Performance of Crossbred Dairy Cows in Eastern lowlands of Ethiopia. Livestock Research for Rural Development 19: 161.

13. Giday Y (2001) Assessment of calf productivity and total herd life of Fogera cows at Andassa ranch in northwestern Ethiopia. MSc thesis, Alamaya University of Agriculture, Ethiopia, pp. 120.

14. Hammoud MH, El-Zarkouny SZ, Oudah EZM (2010) Effect of sire, age at first calving, season and year of calving and parity on reproductive performance of Friesian cows under semiarid conditions in Egypt. Archiva Zootechnica 13(1): 60-82.

15. Ajili N, Rekik A, Gara Ben, Bouraoui R (2007) Relationships among milk production, reproductive traits, and herd life for Tunisian HolsteinFriesian cows. African Journal of Agricultural Research 2(2): 047-051.

16. Tozer PR, Heinrichs AJ (2001) What affects the costs of raising replacement dairy heifers: A multiplecomponent analysis. Journal of Dairy Science 84(8): 1836-1844.

17. Cilek S (2009) Reproductive traits of Holstein cows raised at Polatlistat farm in Turkey. Journal of Animal and Veterinary Advance 8: 1-5.

18. Tadesse MJ, Thiengtham A, Pinyopummin, Prasanpanich S (2010) Productive and reproductive performance of Holstein Friesian dairy cows in Ethiopia. Livestock research for rural development. Volume 22: 2 .

19. Gebregziabher Gebreyohannes, AzageTegegne, Diedhion ML, Hegde BP (2005) Days to first service, conception rate and service period of indigenous and crossbred cows in relation to postpartum body weight change at Bako, Ethiopia. Ethiopian Journal of Animal production 5(1): 83-90.

20. Samsson A (2001) Assessment of the Reproductive performance of Artificially inseminated cattle in and aroundAddis Ababa, DVM thesis, Addis Ababa University, Faculty of Veterinary Medicine, DebreZeit, Ethiopia.

21. Mekonnen T, Bekana M, Abayneh T (2010) Reproductive performance and efficiency of artificial insemination smallholder dairy cows/heifers in and around Arsi-Negelle, Ethiopia. Livestock Research for Rural Development 22: 3.

22. Belachew T (2003) Reproductive periformance and major related fertility problem in female cattle at Abornesa Ranch in centeral rift vally.DVM thesis, Addis Abeba veterinary factuality of veterinary Medicien Debre Zeyt, Ethiopia.

23. Habtamu Lemma, Kelay Belihu, Desie Sheferaw (2010) Study on the reproductive performance of Jersey cows at Wolaita Sodo dairy farm, Southern Ethiopia. Ethiop. Vet J 14(1): 53-70.

24. Ben Salem M, Djemali M, Kayouli C, Majdoub A (2006) A review of environmental and management factors affecting the reproductive performance of Holstein-Friesian dairy herds in Tunisia. Livestock Research for Rural Development 18: 4.

25. Mekonnen Hailemariam, Keno Banjaw, Tefera Gebremeskel, Hiskias Ketema (1993) Productivity of Boran cattle and their Friesian crosses at Abernossa ranch, rift valley of Ethiopia. I. Reproductive performance and preweaning mortality. Tropical Animal Health and Production.
25(4): 239-249.

26. Ray DE, Halbach TJ, Armstrong DV (1992) Season and lactation number effects on milk production and reproduction of dairy cattle in Arizona. Journal of Dairy Science 75(11): 2976-2983.

27. Asseged B, Birhanu M (2004) Survival analysis of calves and reproductive performance of cows in commercial dairy farms in and around Addis Ababa, Ethiopia. Tropical Animal Health and Production. 36(7): 663-672.

28. Gifawosen Tessema, Alemu Geberewold, Azage Tegegne, Diediou ML, Hegde BP (2003) Study on reproductive efficiency of Boran and its crosses at Holetta research farm: Effect of genotype, management and environment. Ethiopian Journal of Animal Production. 3(1): 89-108.

29. Fikru S (1994) Behvioral and physical signs associated with oestrus of fogera cattle and evaluation of some aspect their reproductive performance. DVM thesis, Addis Abeba University, Facuality of veterinary Medicine, Debre Zeit, Ethiopia.

30. Gebregziabher Gebreyohannes, Azage Tegegne, Diedhiou ML, Hegde BP (2003) Reproduction efficiency of zebu and crossbred cows as measured by the inter-estrus and inter-service intervals at Bako, Ethiopia. pp. 111-118.

31. Yoseph S, Tenhagen BA, Merga B, Tesfu K (2003) Reproductive performance of crossbred dairy cows managed under different production systems in central highlands of Ethiopia. Tropical Animal Health and Production 35(6): 551-561.

32. Emebet Moreda (2006) Reproductive performance of dairy cows under urban dairy production systems in dire-dewa, Ethiopia. Ans. M.Sc. thesis Presented to the Department of Animal Sciences, School of Graduate Studies of Haramaya University, Ethipoia.

33. Haileyesus Abate (2006) Evaluation of artificial insemination service efficiency and reproductive performance of $\mathrm{F}_{1}$ friesian crosses in north Gonder zone, ethiopia. in M.Sc. Thesis Presented to the Department of Animal Sciences, School of Graduate Studies of Alemaya University, Ehiopia.

34. Azage $\mathrm{T}$ (1989) Reproductive development and function in zebu and crossbred cattle in Ethiopia. Australia: James Cook University, Dissertation, Ethiopia.

35. Lobago F, Bekana M, Gustafsson H, Kindahl H (2007) Longitudinal observation on reproductive and lactation performances of smallholder crossbred dairy cattle in Fitche, Oromia region, central Ethiopia, Tropical Animal Health and Production 39: 395-403.

36. Geleto A (1991) Effects of nutrition and partial suckling on lactation and reproductive performance of primiparous Boran cows and on growth of their progeny. DVM Thesis. FVM, AAU, Debre Zeit, Addis Ababa, Ethiopia.

37. Rhodes FM, McDougall S, Burke CR, Verkerk GA, Macmillan KL (2003) Invited review: treatment of cows with an extended postpartum anestrous interval. J Dairy Sci 86: 1876-1894.

38. Shiferaw Y, Tenhagen BA, Bekana M, Kassa T (2003) Reproductive Performance of Crossbred Cows in Different Production Systems in the Central High Lands of Ethiopia. Trop. Ani. Health and Prod 35: 551-561. 
This work is licensed under Creative Commons Attribution 4.0 License DOI: 10.19080/JDVS.2018.07.555713
Your next submission with Juniper Publishers will reach you the below assets

- Quality Editorial service

- Swift Peer Review

- Reprints availability

- E-prints Service

- Manuscript Podcast for convenient understanding

- Global attainment for your research

- Manuscript accessibility in different formats

( Pdf, E-pub, Full Text, Audio)

- Unceasing customer service

Track the below URL for one-step submission https://juniperpublishers.com/online-submission.php 